\title{
Students' Cognitive and Attitude of Secondary School in Learning Global Warming using Student Team Achievement Division (STAD) based on Gender
}

\author{
Melvin Aldila¹, Fransisca Sudargo Tapilouw², Yayan Sanjaya²* \\ ${ }^{1}$ Department of Science Education, Faculty of Mathematics and Science Education, Universitas Pendidikan Indonesia, Indonesia \\ ${ }^{2}$ Department of Biology Education, Faculty of Mathematics and Science Education, Universitas Pendidikan Indonesia, Indonesia \\ *Corresponding Author. yayansanjaya229@gmail.com
}

\begin{abstract}
This study was intended to investigate students' cognitive and attitude of secondary school in learning global warming using Student Team Achievement Division (STAD) based on gender. This study was conducted at one of bilingual boarding school in Bandung. This study uses the quasi-experimental method with matching pretest-posttest comparison group design while the number of subject in the girl class is $15(\mathrm{~N}=15)$ and in the boy class is $15(\mathrm{~N}=15)$. Data was gained through a cognitive test which measured by Bloom's taxonomy cognitive level (C1-C6), a questionnaire which measured by Test of Science Related Attitude (TOSRA). The result shows that student who learns global warming using STAD has an improvement on their cognitive score, especially in the girl class. Meanwhile, girl class has higher students' attitude result in three scales of TOSRA that are; attitude to scientific inquiry, adoption of a scientific attitude, and enjoyment of science lessons. Along with the students' cognitive result, girl class also has a better science-related attitude than the boy class. Thus, it can be concluded that there is a significant difference between students' cognitive and attitude at the girl and boy class in learning global warming using STAD.
\end{abstract}

Keywords Student Team Achievement Division, Students' Cognitive, Students’ Attitude, Global Warming, Gender

\section{INTRODUCTION}

Cooperation is the basic characteristic of human beings. Most of our attitudes and values are formed by discussing, what the researcher knows of think of others (Pandey \& Kishore, 2003). The researcher also could apply the cooperation form of learning and the method called cooperative learning. Cooperative learning is a method used by educators that can help students to develop necessary social skills. Healthy interaction skills, the success of the individual student and group members, and the formation of personal and professional relationships are the results of cooperative learning (Johnson \& Johnson, 1999).

According to Bätz, Wittler, \& Wilde (2010), the study was completed in the last three decades have shown that girls and boys have different interests and attitudes toward studying science and different perceptions of scientists and science careers. In addition, students often report having had different experiences with science in and out of school based on gender (Putri, Rusyati, \& Rochintaniawati, 2018). Recently, related with previous research that conducted by Ormrod (2008), boys do slightly better on visual-spatial task, and girls are slightly better at the verbal task. Girls consistently earn higher grade at school. It can be interpreted that the achievement between boys and girls are different, while in an educational implication expected that boys and girls to have similar cognitive and academic skill. Ormrod (2008) also stated that boys tend to exhibit more in physical aggression and girls tend to be more affiliated. Boys feel more comfortable in a competitive situation, girls prefer cooperative environments, while in an educational implication expected that teacher should teach both genderless aggressive ways to interact and provide a cooperative environment for all. The finding of the research conducted by Ormrod (2008) also showed that in terms of motivation girls, in general, are more concerned about doing well in school. They tend to work harder but take fewer risks, while in an educational implication expected that boys and girls to excel in all subjects except in science.

Received: 29 June 2018

Revised: 2 August 2018

Published: 11 August 2018 
One of the major objectives of teachers is to use effective instructional strategies to improve students' cognitive and affective outcomes. In recent years, studies involving cooperative learning, one kind of studentcentered approach such as methods have emerged as an internationally important area of social science research among researchers (Slavin, 2010). According to Johnson, Johnson \& Stanne (2000), when students worked in groups, a student could enhance their academic content. Prima, Putri, \& Sudargo (2017) applied pre and post roleplays to improve students' understanding. Wardani \& Winarno (2017) applied inquiry-based laboratory activities in lights and optics topic to improve students' understanding. Pratiwi, Rochintaniawati, \& Agustin (2018) conducted multiple intelligence-based learning to enhance students' concept mastery and interest. Zakaria, Chin \& Daud (2010) concluded that there are positive changes take place when a teacher changes his teaching method towards a more student-centered approach. A researcher could analyze the student-centered teaching approach through the Student Teams Achievement Divisions (STAD) learning approach. As stated by Slavin (2010), in order to encourage students to improve their achievement and promote more positive attitude, an alternative to lecturebased teaching could be Student Teams Achievement Divisions (STAD), one kind of cooperative learning approach. Student Teams Achievement Divisions (STAD) is a very easy model to implement in the science classroom. As in the entire cooperative learning models to follow, STAD operates on the principle that student works together to learn and are responsible for their teammate's learning as well as their own (Hassard \& Dias, 2008).

The limitation of time also has been a problem for a teacher to deliver the science concept. The teacher should find the proper way to deliver the science concept in a very limited time. Usually, the time to deliver the concept in secondary school is approximately eighty minutes. Thus, STAD as a cooperative learning could help the teacher in overcoming the time limitation since STAD is a very easy model to implement in the science classroom (Slavin, 2010). However, among different cooperative learning methods, STAD is easy for teachers to apply and can be used to teach a variety of subjects from primary to university level. In this scenario, it seemed plausible to investigate the reflection of STAD (student team achievement division) in the classroom in term of active learning strategy (Majoka, Dad, \& Mahmood, 2010).

Global Warming is one of the topics that suitable with STAD method itself since Global Warming contains several problems about a natural phenomenon that should be solved by discussion and STAD would help the teaching-learning process since STAD make the student interact each other to discuss and find the way to solve the Global Warming issues. With the current study, it was aimed to determine how the result of students' cognitive and attitude of a secondary school student in learning global warming based on gender. This study outlines a framework to investigate the result of students' cognitive and attitude between girls and boys classes in learning science.

\section{METHOD}

The method that used in this research is a QuasiExperimental method (Creswell, 2012). The research design that used in this research is two group pre-test posttest designs (Sukmadinata, 2011). The location of this research is Bilingual Boarding School in Bandung. The school used both English and Bahasa Indonesia as an instructional language and implementing the National Curriculum of 2013 combined with Zambak Modular system. The population in this research is $7^{\text {th }}$-grade students. The samples are two classes in seventh grade, which are girl class and boy class. The sampling technique that used is Purposive Sampling (Fraenkel \& Wallen, 2007).

There are three types of instrument that are used in this research. Those instruments are; Objective Test which included pretest and posttest which will be used to measure students' cognitive. It contains 25 multiple choice question based on Bloom's Taxonomy revised (C1-C6). The questionnaire that used as a tool to measure students' attitude toward science after learning about global warming. This questionnaire is developed by Fraser (1981) named Test of Science Related Attitudes (TOSRA). Since this research conducted to measure the students' attitude towards global warming lessons, thus researcher only choose 3 scales from overall 7 scales, which are; Attitude to Scientific Inquiry, Adoption of Scientific Attitudes, Enjoyment of Science Lessons. With the total number of statement-question is 30 . Observation Sheet that used to ensure the teaching process using Student Team Achievement Division (STAD) design. It will assess whether the step of teaching is already suitable for the Student Team Achievement Division (STAD) stages or not. The entire instrument is judged and validated by the expert before used to gain the data.

\section{RESULT AND DISCUSSION 3.1 Students' Cognitive}

All the data gained from this research is analyzed using IBM SPSS Statistics 20.0. Firstly, the gain score is calculated, then the N-Gain is also calculated after getting the value of the N-Gain itself, the Kolmogorov-Smirnov normality test is done. Since one of the data has 0.038 significance values in the normality test, it means that the data gained is not normal because the minimum significance value for normal data should be $\geq 0.05$. After the normality test, Kolmogorov-Smirnov is done and the result of the data is not normal thus nonparametric Mann - Whitney statistic in order to test the hypothesis should be conducted. 
STAD as a treatment of the research has been successfully conducted, the pretest and the posttest has been conducted as well. According to the result of comparing mean analysis, there is an improvement of students result between pretest and posttest in both girl and boy class. According to the result, the average N-Gain in girl class is higher than the average N-Gain in boy class $(0.77>0.29)$ (Table 1$)$.

The average N-Gain value above both in girl class and boy class after learning with STAD has improved. This is in line with the statement of former research which stated that cooperative learning significantly enhances the science achievement of students compared to the traditional method (Pandey \& Kishore, 2003). The results showed that the treatment group which had engaged in STAD learning approach produced a higher overall improvement in scores on the post-test. The result also stated that cooperative learning significantly enhances the knowledge of science as compared to a traditional method of teaching (Tran, 2013).

The result of the average N-Gain value in girl class is 0.77 , while the gain average in boy class is 0.29 . The result of the average $\mathrm{N}$-Gain value indicates that the quality of improvement in students' cognitive after STAD implementation is categorized into the high category for the girl class while low category for boy class. In term of the using cooperative learning as a learning approach, girl rated cooperative school activities more positively than boy did (Gomleksiz, 2012). This is in line with the findings of the former study that can be seen in relation to the better grades of girls in school (Bätz, Wittler, \& Wilde, 2010). However, there are some other studies indicating that female students perceive the biology learning environment more favorably than male students do. Generally, girls' interest in Biology subject is higher than boys. It is related with the result of this research since the course that thought to the students in both of girl and boy class is global warming which includes in biology it might be one factor that affected on students' cognitive improvement among girl and boy class.

Meanwhile, the students' cognitive itself also can be analyzed from every cognitive level from C1 (remembering) until C6 (creating). First, the data of pretest and posttest have to be separated based on every cognitive level (C1 - C6), then find the gain score and N-Gain value from every cognitive level as stated in Table 2. According to Table 2, the improvement of students' cognitive could be seen clearly from C1 (remembering), C2 (understanding), C3 (applying), C4 (analyzing), C5 (evaluating), and C6 (creating). The result of cognitive level 5 (evaluating) and cognitive level 6 (creating) above are in line with the findings of the former research about Gender Differences for 6-12th Grade Students over Bloom's Cognitive Domain, which stated that girls outperformed boys on all test formats and at every cognitive level. Girl outperformed boys significantly at the cognitive levels 5 (evaluating) and 6 (creating). When it's compared between the mean responses of boys and girls at each level, it's noticed that girls outperformed boys significantly in analytical ability (Bastick, 2002).

The overall result of students' cognitive on both of girl class and boy class showed that girls outperformed boys in every cognitive level from C1 (remembering) until C6 (creating) it is supported by the findings of the former research which is stated that from middle childhood up to the age of 18 years boys tended to perform less well on standardized tests of achievement and there were consistent tendencies for boys to perform less well than girls (Ferguson \& Horwood, 1997). It is also strengthened by this statement; it could be proposed that the consistently poorer academic performance of boys was due to the fact that boys were cognitively less able than girls. The clear interpretation of the results is that boys and girls were populations of very similar cognitive ability but were distinguished by girls having better academic achievement than boys (Ferguson \& Horwood, 1997).

Based on all the discussion above it can be concluded that implementation of Student Team Achievement Division (STAD) have improved students' cognitive result both in girl and boy classes even though the girl class has higher cognitive level improvement rather than boy class.

\subsection{Students' Attitude}

Students' attitude both in a girl and boy class is known for the Test of Science Related Attitudes (TOSRA) questionnaire that is given after learning global warming using Student Team Achievement Division (STAD). The questionnaire itself is given by all the students in both classes did their posttest. There are 3 scales that become an indicator of students' attitude itself; they are the attitude to scientific inquiry, adoption of a scientific attitude, and enjoyment of science lesson.

The result of the questionnaire is obtained using the Likert-scale. The questionnaire itself consists of 30 statements which divided into 15 positive statements and 15 negative statements. The score range for each degree is different from 1 up to 4, each indicator has a couple of positive and negative statement and the order of the score inversely calculated. The recapitulation of the result of students' attitude after learning global warming using STAD in girl and boy classes is described in Figure 1.

According to the Figure 1, there is a significant difference students' attitude result from girl and boy classes. The highest value in both girl and boy class is on the second scale which is the adoption of a scientific attitude, although the girl class has a higher score than a boy class $(76.26 \%>67.74 \%)$. Followed by the enjoyment of science lesson scale in the girl class which got the value $65.74 \%$ while the boy class only got $65.46 \%$. The last is the attitude to scientific inquiry scale where the girl class still 


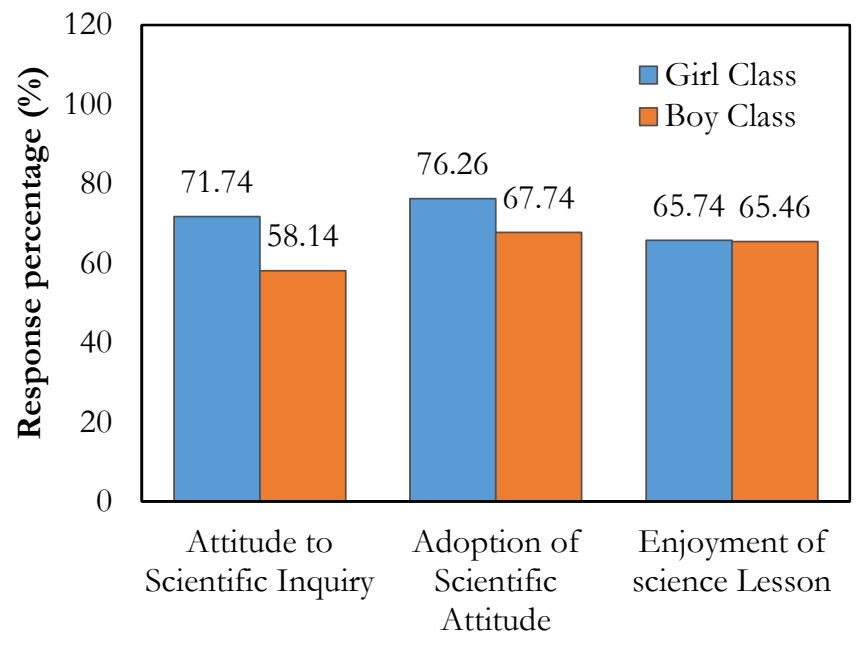

Students' attitudes

Figure 1 Students' attitude result in girl and boy classes

got the higher value than the boy class $(71.74 \%>58.14 \%)$. From the data above, it can be concluded that students' science-related attitude after learning about global warming using STAD in the girl class is higher than in the boy class. Students' attitude both in a girl and boy class is known by the answer to a questionnaire that is given after the learning process using the Student Team Achievement Division (STAD). The questionnaire itself adapted from Fraser (1981) called Test of Science Related Attitude (TOSRA).

TOSRA is designed to measure science-related attitudes scales among secondary school students. TOSRA originally has seven scales to analyze which are; Social Implications of Science, Normality of Scientists, Attitude to Scientific Inquiry, Adoption of Scientific Attitudes, Enjoyment of Science Lessons, Leisure Interest in Science, and Career Interest in Science. Since this research conducted to measure the student's attitude towards global warming lessons, thus researcher only choose 3 scales from that 7 scales, which are; Attitude to Scientific Inquiry (I), Adoption of Scientific Attitudes (A), and Enjoyment of Science Lessons (E) because the statement-questions sample of another four indicators are not representative of the attitude scales that researcher want to measure. There are 70 statement-questions in the questionnaire and every 10 questions represented one scales. But since the researcher only uses 3 scales thus; the total number of statement-question is 30 . The form of the TOSRA questionnaire could be seen in the appendices.

The result shows that overall students' attitude in both girl and boy classes has significant differences. As stated before, there are three scales of TOSRA that examined by the researcher. Each aspect has a result which is different. The result of all scales is higher in the girl class rather than boy class. This result is supported by the research of AbuHola (2005) who stated that females had more positive attitudes towards science than males in the same grade.
While Abu-Hola (2005) stated that girls participated actively in science compared with boys. Few studies have been reported where girls' performance on biological topics is significantly better than that of boys. This must be one factor that affected the result. Since the topic that students learned is global warming which is part of the biological topic (science), thus it can be concluded that girl class much more actively give the positive attitude on science than the boy class.

The result also in line with the findings of research that conducted by Tran (2013) which stated that that the treatment group, which had engaged in STAD learning approach, produced a higher overall improvement in scores on attitude scales. From overall result and discussion above it can be concluded that students' attitude of secondary school in learning global warming using Student Team Achievement Division (STAD) based on gender is greater on the girl class rather than the boy.

\section{CONCLUSION}

The implementation of Student Team Achievement Division can improve students' cognitive, it can be known by processing the differences in average N-Gain value in both girl and boy classes. The highest average N-Gain value is obtained by girl class which has 0.77 then followed by the average $N$-Gain value of boy class which has 0.29 . It shows that there is a significant effect of Student Team Achievement and Division (STAD) since the average $N$ Gain value is not has a negative value. Thus, girl class has a higher cognitive level than boy class after treated by Student Team Achievement Division (STAD).

The implementation of Student Team Achievement Division also can affect students' attitude. Girl class has higher students' attitude result in three scales of TOSRA which are; attitude to scientific inquiry, adoption of a scientific attitude, and enjoyment of science lessons. Along with the students' cognitive, girl class has a better sciencerelated attitude than the boy class.

\section{ACKNOWLEDGMENT}

The authors acknowledge the principal, teachers, and students of Pribadi Billingual School, Indonesia.

\section{REFERENCES}

Abu-Hola, I. (2005). Uncovering gender differences in science achievement and attitudes towards science for Jordanian primary pupils. Damascus University Journal, 21(1), 19-53.

Bätz, K., Wittler, S., \& Wilde, M. (2010). Differences between boys and girls in extracurricular learning settings. International Journal of Environmental \& Science Education, 5(1), 51-64.

Bastick, T. (2002). Gender Differences for 6-12th Grade Students over Bloom's Cognitive Domain. [Online]. Retrieved from http:// eric.ed.gov/.

Creswell, W. J. (2012). Educational Research: Planning, Conducting and Evaluating Quantitative and Qualitative Research (4th ed). Boston USA: Pearson Education, Inc.

Fergusson, D. M., \& Horwood, L. J. (1997). Gender differences in educational achievement in a New Zealand birth cohort. New Zealand Journal of Educational Studies, 32, 83-96. 
Fraenkel, J. R., \& Wallen, N. E. (2007). How to Design and Evaluate Research in Education, Sixth Edition. New York: Mc-Graw Hill.

Fraser, B, J. (1981). Test of Science-Related Attitudes. [Online]. Retrieved from http:/ / wnw.pearweb.org/.

Gömleksiz, M. N. (2012). Elementary school students' perceptions of the new science and technology curriculum by gender. Journal of Educational Technology \& Society, 15(1), 116-126.

Hassard, J., \& Dias, M. (2008). Cooperative Learning Models. [Online]. Retrieved from http:/ / cw.routledge.com/.

Johnson, D. W., \& Johnson, R. T. (1999). Making cooperative learning work. Theory into practice, 38(2), 67-73.

Johnson, D. W., Johnson, R. T., \& Stanne, M. B. (2000). Cooperative learning methods: A meta-analysis, 1-17.

Majoka, M. I., Dad, M. H., \& Mahmood, T. (2010). Student team achievement division (STAD) as an active learning strategy: Empirical evidence from mathematics classroom. Journal of Education and Sociology, 4, 16-20.

Pandey, N, N., and Kishore, K. (2003). Effect of Cooperative Learning on Cognitive Achievement in Science. Journal of Science and Mathematics Education in Science Education Asia. 26(2), 52-60.

Pratiwi, W. N. W., Rochintaniawati, D., \& Agustin, R. R. (2018). The Effect of Multiple Intelligence-Based Learning Towards Students' Concept Mastery and Interest in Matter. Journal of Science Learning, 1(2), 49-52.
Prima, E. C., Putri, C. L., \& Sudargo, F. (2017). Applying Pre and Post Role-Plays supported by Stellarium Virtual Observatory to Improve Students' Understanding on Learning Solar System. Journal of Science Learning, 1(1), 1-7.

Putri, A. U., Rusyati, L., \& Rochintaniawati, D. (2018). The Impact of Problem-Solving Model on Students' Concept Mastery and Motivation in Learning Heat Based on Gender. Journal of Science Learning, 1(2), 71-76.

Slavin, R. E. (2010). Co-operative learning: what makes group-work work. The nature of learning: Using research to inspire practice, 161-178.

Sukmadinata, N, S. (2011). Metode Penelitian Pendidikan. Bandung: Remaja Rosdakarya.

Tran, V. D. (2013). Effects of student teams achievement division (STAD) on academic achievement, and attitudes of grade 9th secondary school students towards mathematics. International Journal of Sciences, 2(2013-04), 5-15.

Wardani, T. B., \& Winarno, N. (2017). Using Inquiry-based Laboratory Activities in Lights and Optics Topic to Improve Students' Understanding About Nature of Science (NOS). Journal of Science Learning, 1(1), 28-35.

Zakaria, E., Chin, L. C., \& Daud, M. Y. (2010). The effects of cooperative learning on students' mathematics achievement and attitude towards mathematics. Journal of social sciences, 6(2), 272-275. 
